\title{
EFFECT OF AUSTENITIC GRAIN SIZE ON THE PHASE TRANSFORMATION OF A NOVEL 6.5\% Cr STEEL FOR FORGED COMPONENTS
}

\author{
Andrea Di Schino ${ }^{l)^{*}}$ \\ ${ }^{1)}$ Università degli Studi di Perugia, Dipartimento di Ingegneria, Perugia, Italy
}

Received: 17.10.2018

Accepted: 21.02.2019

${ }^{*}$ Corresponding author: andrea.dischino@ unipg.it, Tel.+390744 492953,Dipartimento di Ingegneria, Università di Perugia, Via G. Duranti, 01625 Perugia, Italy

\begin{abstract}
In this paper the effect of quenching and tempering (Q\&T) thermal treatment on mechanical properties of a novel $6.5 \% \mathrm{Cr}$ steel for forged components is studied. The main innovation is in the increased hardenability following the higher $\mathrm{Cr}$ content with respect to the more common $5 \% \mathrm{Cr}$ steel allowing to lower the content of other chemical elements aimed to achieve the target mechanical properties. Following to the high intrinsic hardenability of such steel based on the $\mathrm{Cr}$ content a poor effect of prior austenite grain size should be expected after quenching. Aim of this work is to evaluate such effect and to analyse the dependence of mechanical properties on it.
\end{abstract}

Keywords: Cr content, heat treatment, mechanical properties

\section{Introduction}

Mechanical properties in steel can be improved by adding alloying elements. Among them the most commonly used are chromium and molybdenum. Different strengthening mechanism can be activated depending on final product properties to be targeted. The standard methods used for strengthening steels are $[1,2]$ :

- microstructure refinement,

- solution hardening,

- dislocation strengthening,

- precipitation hardening.

It has been reported that the tensile properties are strongly dependent on grain size and such mechanism should increase the yield strength up to three times [3-4]. Moreover, such method can allow the best strength/toughness combination [5-7]. Solution hardening allows to increase fatigue and high temperature behavior [8-10]. Anyway, both methods could be difficult or quite expensive since are affected by the cost of the elements to be added at the steel composition. This paper will focus mainly on the quenching and tempering strategy adopted for steels for forgings [11-13] with enhanced Cr content. Quenching and tempering (Q\&T) is one of the most common heat treatment processes after forging. Although forging could increase the product strength, usually the actual hardness values are still poor. Heat treatments are generally carried out after forging aimed to achieve the target mechanical properties. It is the combination of these two processes (forging and heat treatment) that allows to achieve a harder, tougher part that's easier weldable and ductile than ordinary carbon steel. However, producing forgings using the Q\&T is inefficient and deleterious to the environment and alternative routes to high strength 
forgings have been studied for decades [14]. For flat C-Mn steel rolled product the addition of microalloying elements is usually adopted to increase tensile properties [15-20]. Thus, vanadium micro-alloying is predominant in these steels, although growing importance is being placed on dual additions of vanadium with lower levels of niobium. Nitrogen additions are useful to enhance precipitation strengthening in the vanadium applications [21-24]. Moreover, increased yield strength can be achieved by improving hardenability and $\mathrm{Cr}$ is usually added with increasing material costs.

These micro-alloying strategies are increasingly employed to enhance strength and performance, or to reduce the number of heat-treating steps while maintaining adequate mechanical performance.

\section{Experimental materials and methods}

A steel with chemical composition $0.30 \% \mathrm{C}-0.70 \% \mathrm{Mo}-6.50 \% \mathrm{Cr}-0.65 \% \mathrm{Mn}$, measured by Quantitative Spectroscopy Analysis, is considered in the following. The steel was manufactured by Electroslag Remelting process (ESR) resulting in higher internal quality ingots. From the ingot, specimens have been cut for Continuous Cooling Temperature (CCT) curves determination. CCT curves were determined by means of dilatometry measurements carried out on $5 \mathrm{~mm}$ length $1 \mathrm{~mm}$ diameter specimens, with controlled cooling rate. After cooling all specimens were analyzed for hardness and microstructure by Light Microscopy (LM). Phase transformations have been studied and, following to it, quenching and tempering (Q\&T) treatments have been performed starting from two different austenitization temperatures $\left(980^{\circ} \mathrm{C}\right.$ and $1200^{\circ} \mathrm{C}$ ) followed by cooling at the rate defined by CCT and tempering at different temperatures. Microstructure analysis and hardness measurements of heat treated specimens have been carried out by means of Light Microscopy (LM) after 4\% Nital etching and $2 \mathrm{Kg}$ Vickers indenter $\left(\mathrm{HV}_{2}\right)$. Room temperature tensile tests were carried out according to ISO 68921 specification.

\section{Results}

Dilatometric curves of the selected steel after austenitization at $980^{\circ} \mathrm{C}$ and $1200^{\circ} \mathrm{C}$ are reported in Fig. 1. The built CCT diagram based on such curves are shown in Fig. 2.

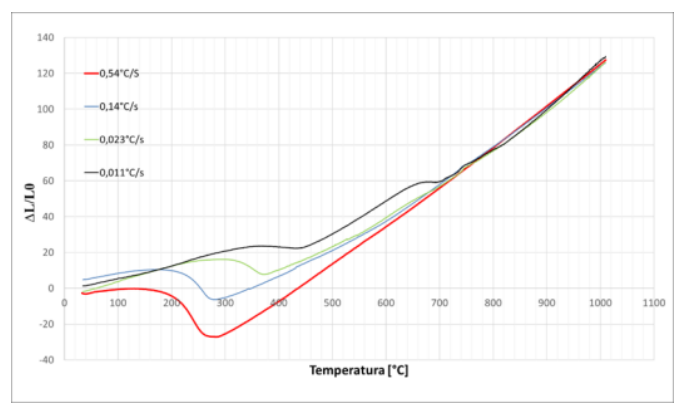

A

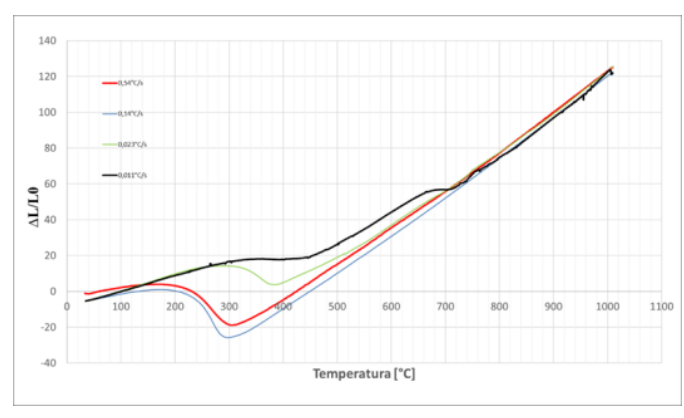

B

Fig. 1 Dilatometry curves of the considered steel: a) austenitization at $980{ }^{\circ} \mathrm{C}$; b) austenitization at $1200^{\circ} \mathrm{C}$ 


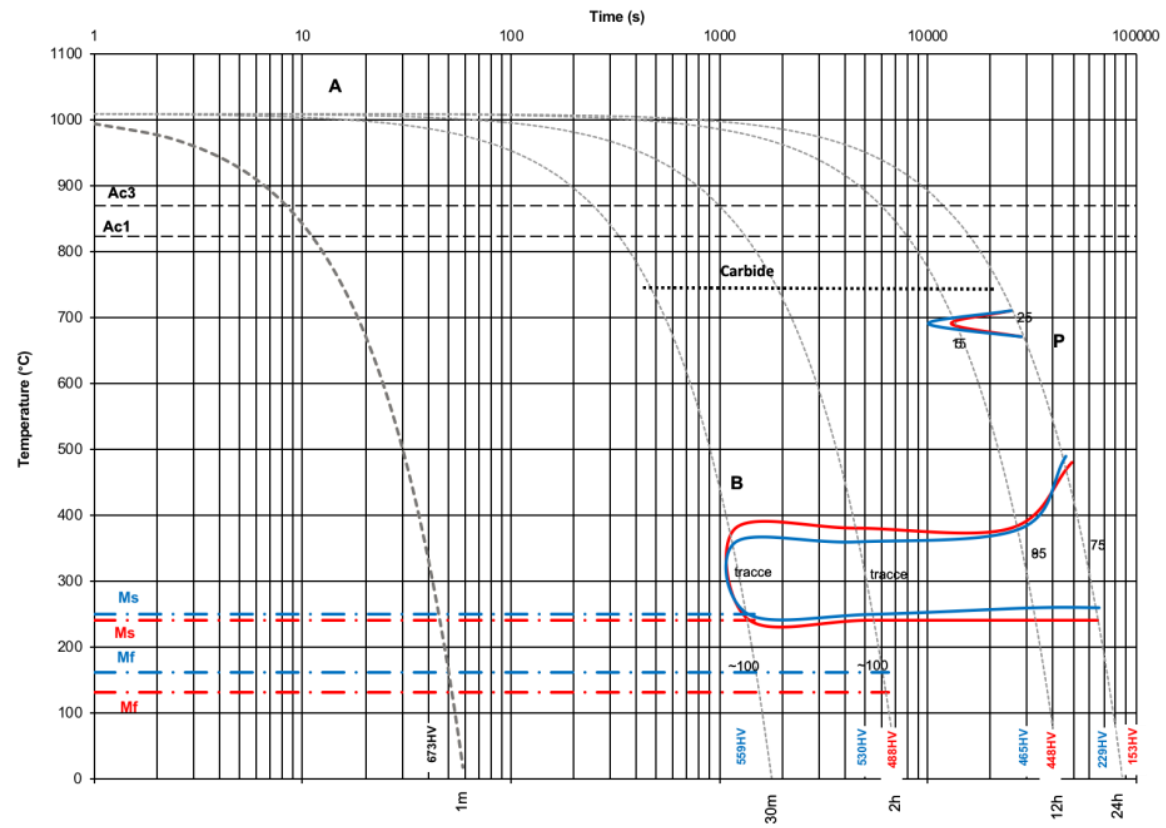

Fig. 2 CCT diagrams of the selected steel (red curve: austenitizationa at $980^{\circ} \mathrm{C}$; blue curve: austenitizationa at $1200^{\circ} \mathrm{C}$ )

Results reported in Figs. 1 and $\mathbf{2}$ show that for such high Cr steel, a negligible austenitization temperature effect is found to be on the cooling behaviour, following the high intrinsic hardenability, even if a strong difference holds is found in terms of prior austenitic grain size (Fig. 3).

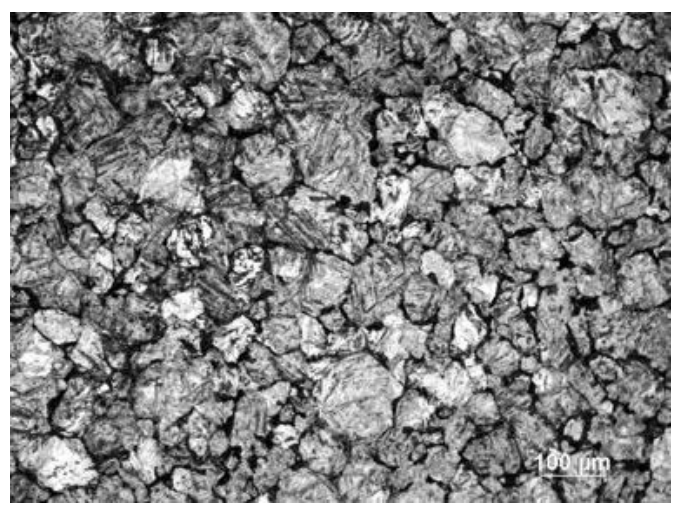

A

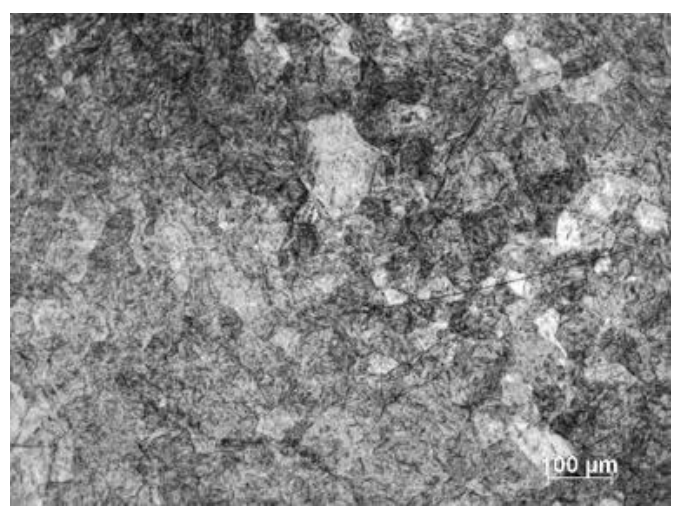

B

Fig. 3 Austenitic grain size of two specimens after austenitization at $980{ }^{\circ} \mathrm{C}$ (a) and $1200{ }^{\circ} \mathrm{C}$ (b)

Based on results reported in Fig. 2, specimens were austenitized at $980^{\circ} \mathrm{C}$, air cooled to achieve a fully ferritic-pearlitic microstructure (reproducing what is found in forgings); specimens were 
tempered in the range $540^{\circ} \mathrm{C}-660^{\circ} \mathrm{C}$ for 30 minutes holding time. The microstructure obtained after cooling is reported in Fig. 4. It is fully ferritic and pearlitic, as expected following Fig. 1. Hardness measurements performed on quenched and tempered materials are shown in Fig. 4. Results show that values do not significantly change in the range of the tempering temperature as expected in the case of microstructure mainly constituted by ferrite and pearlite (Fig. 5). Results of tensile tests Q\&T materials after tempering at $640^{\circ} \mathrm{C}$ are reported in Table 1.

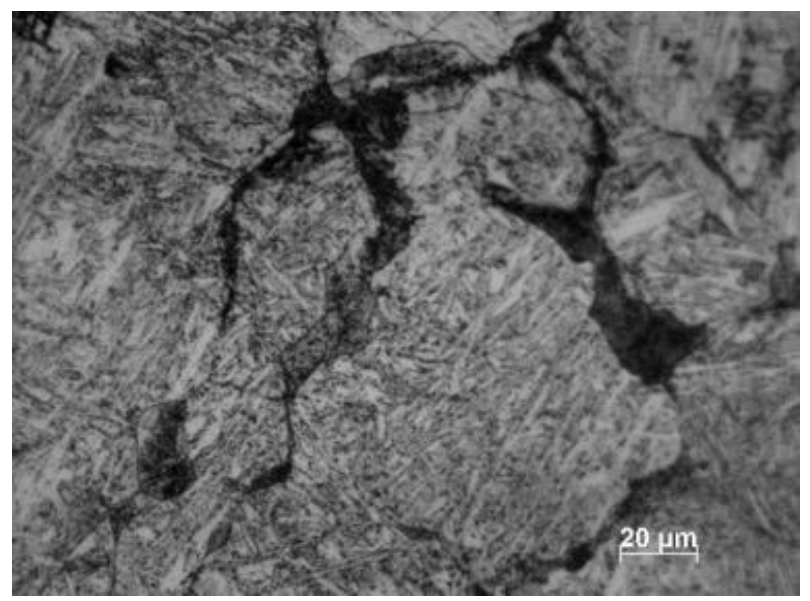

Fig. 4 Microstructure after austenitization and cooling: austenitization temperature $=980^{\circ} \mathrm{C}$

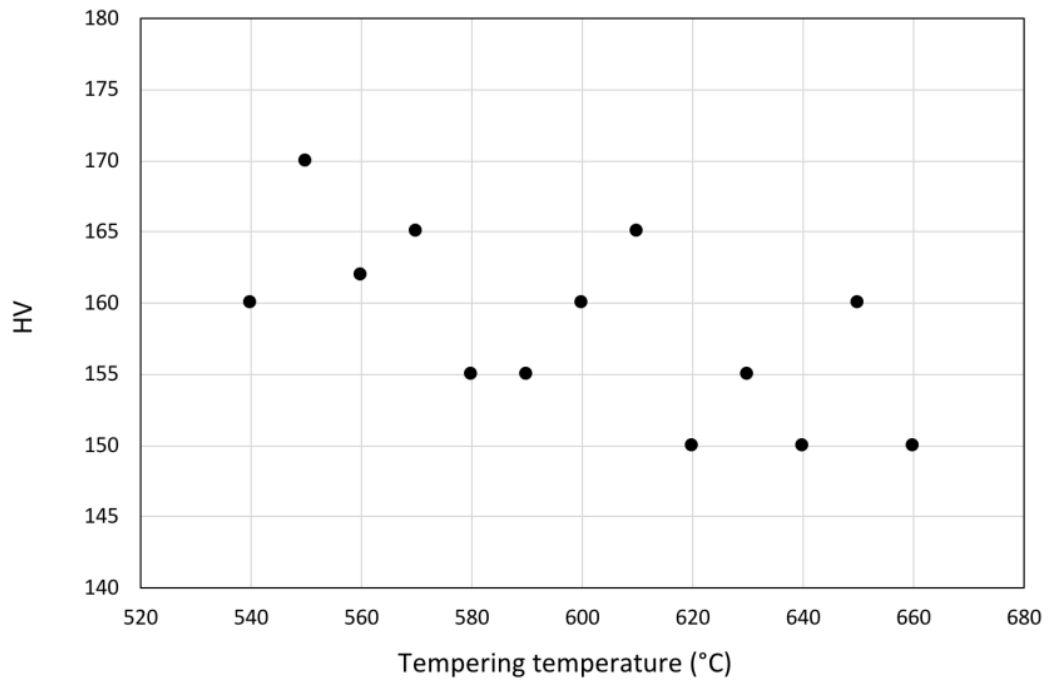

Fig. 5 Effect of tempering on hardness. Austenitization time: $30 \mathrm{~min}$, tempering time: $30 \mathrm{~min}$

Table 1 Tensile properties of material austenitized at $980^{\circ} \mathrm{C}$ and tempered at $\mathrm{T}=640^{\circ} \mathrm{C}$

\begin{tabular}{|c|c|c|c|}
\hline Austenitization temperature $\left({ }^{\circ} \mathrm{C}\right)$ & $\mathrm{R}_{\mathrm{m}}[\mathrm{MPa}]$ & $\mathrm{R}_{\mathrm{p}} 0.2[\mathrm{Mpa}]$ & $\mathrm{A}, \%$ \\
\hline 980 & 966.4 & 739.9 & 18.3 \\
\hline 1200 & 737.6 & 407.6 & 20.3 \\
\hline
\end{tabular}




\section{Discussion}

Results show that in the case of $6.5 \% \mathrm{Cr}$ steel, following the high intrinsic hardenability, the austenitic grain size effect on microstructure after cooling is really poor. Based on this result the same behaviour in terms of microstructure is found after austenitization at $1200{ }^{\circ} \mathrm{C}$ (typical forging process temperature) or $980{ }^{\circ} \mathrm{C}$ (typical heat temperature applied to final product). It is worth to be mentioned that in many cases this should allow to avoid the final Q\&T treatment, just adopting the material in the as-forged condition. Nonetheless, the adoption of a final heat treatment (anyway independent on tempering temperature) should allow to increase the tensile properties, as a result of the ferrite refinement following the austenite grain size refining effect.

\section{Conclusion}

In this work the effect of quenching and tempering (Q\&T) thermal treatments on mechanical properties of a $\mathrm{C}-\mathrm{Mn}$ steel with $6.5 \% \mathrm{Cr}$ for forged components has been studied on a laboratory scale. Results show that the microstructure obtained after Q\&T treatments is almost totally ferritic and pearlitic and the hardness of Q\&T samples does not change in the range of $540^{\circ} \mathrm{C}$ to $660^{\circ} \mathrm{C}$ of tempering temperature. Results show the possibility to increase tensile properties if such steel based on a Q\&T process also in absence of an effect due to the austenitisation temperature.

\section{References}

[1] T. Kvackaj, I. Mamuzic: Metalurgija, Vol. 45, 2006, No. 1, p. 51-55

[2] T. Kvackaj et al.: Acta Polonica Physica A, Vol. 126, 2014, No. 1, p. 184-185, DOI: 10.12693/APhysPolA.126.184

[3] A. Di Schino, J.M. Kenny, I. Salvatori, G. Abbruzzese: Journal of Materials Science, Vol. 22, 2001, p.593, DOI: 10.1023/A:1004856001632

[4] R. K. Ray, J. J. Jonas, R. E. Hook: International Materials Reviews, Vol. 39, 1994, p.129, DOI: $10.1179 /$ imr.1994.39.4.129

[5] A. Di Schino, C. Guarnaschelli: Materials Science Forum, Vol. 638-642, 2010, p.3188, DOI: 10.4028/www.scientific.net/MSF.638-642.3188

[6] R. Song, D. Ponge, D. Raabe, J. G. Speer, D. K. Matlock: Materials Science and Engineering A, Vol. 441, 2006, p.1, DOI: 10.1016/j.msea.2006.08.095

[7] F. G. Caballero, H. K. D. H. Bhadeshia: Current Opinion in Solid State and Materials Science, Vol. 8, 2004, p.251, DOI: 10.1016/j.cossms.2004.09.005

[8] A. Di Schino, M. Barteri, J.M. Kenny: Journal of materials Science Letters, Vol. 22, 2003, p.1511, DOI: 10.1023/A:1026155215111

[9] A. Di Schino, J.M. Kenny, M. Barteri: Journal of materials Science Letters, Vol. 22, 2003, p.691, DOI: 10.1023/A:1023675212900

[10] M. Corradi, A. Di Schino, A. Borri, R. Rufini: Construction and Building Materials, Vol. 181, 2018, p. 335, DOI: 10.1016/j.conbuildmat.2018.06.034

[11] A. J De Ardo, C. I Garcia, M. Hua: Metallurgia Italiana, 2010, p. 5

[12] A. Di Schino, L. Alleva, M. Guagnelli: Materials Science Forum, Vol. 715-716, 2012, p. 860, DOI: 10.4028/www.scientific.net/MSF.715-716.860

[13] A. J De Ardo: International Materials Reviews, Vol. 48, 2003, p. 371

[14] A. Steinen, K. Vetterm: Harterei Techn Mitt, Vol. 29, 1974, p. 169

[15] A. Di Schino, P. Di Nunzio, Acta Metallurgica Slovaca, Vol. 23, 2017, p. 62, DOI: 10.12776/ams.v23i1.852 
[16] A. Di Schino, P.E Di Nunzio: Materials Letters, Vol. 186, 2017, p. 86, DOI: 10.12776/ams.v23i1.836

[17]A. Di Schino: Acta Metallurgica Slovaca, Vol. 22, 2016, p. 266, DOI: 10.12776/ams.v22i4.815

[18] A. Di Schino, J.M. Kenny, G. Abbruzzese: Journal of materials Science, Vol. 37, 2002, p.5291, DOI: 10.1023/A:1021068806598

[19] A. Di Schino, P.E: Di Nunzio, L. Turconi: Materials Science Forum, Vol. 558-559, 2007, p. 1435, DOI: $10.4028 / 0-87849-443-x .1435$

[20]Y.Li, J.A. Wilson: ISIJ International, Vol. 44, 2004, p.1093, DOI: 10.2355/isijinternational.44.1093

[21] G. Bregliozzi, S.I. Ahmed, A. Di Schino, J.M. Kenny, H. Haefke, Tribology Letters, Vol. 17, 2004, p. 697, DOI: $10.1007 / \mathrm{s} 11249-004-8075-\mathrm{z}$

[22] D.T. Llewllyn: Ironmaking and Steelmaking, Vol. 20, 1993, p. 338

[23] A. Di Schino, M. Longobardo, G. Porcu, G. L. Turconi, L. Scoppio: NACE- International Corrosion Conference Series, 2006, 06125-0612514

[24]R. Rufini, O. Di Pietro, A. Di Schino: Metals, Vol. 18, 2018, 519, DOI: 10.3390/met8070519 